\title{
Facile and Novel Strategy for Methods of Extraction of Biofuel Grade Lipids from Microalgae- an Experimental Report
}

\author{
Edachery Baldev ${ }^{1}$, Davoodbasha MubarakAli ${ }^{2}$, Masilamani Dhivya ${ }^{1}$, \\ Mahalingam Kanimozhi ${ }^{1}$, Thajuddin Shakena-Fathima ${ }^{1}$, Naiyf S. Alharbi ${ }^{3}$, \\ Chinnathambi Arunachalam ${ }^{3}$, Sulaiman Ali Alharbi ${ }^{3}$ and Nooruddin Thajuddin ${ }^{1,3,}$
}

\author{
${ }^{1}$ Division of Biodiversity and Bioenergy, Department of Microbiology, Bharathidasan University, \\ Tiruchirappalli- 620 024, Tamil Nadu, India \\ ${ }^{2}$ Microbial Molecular Biology Laboratory, Division of Bioengineering, Incheon National University, Republic of \\ South Korea \\ ${ }^{3}$ Department of Botany and Microbiology, College of Science, King Saud University, Riyadh -11451, Kingdom \\ of Saudi Arabia
}

\begin{abstract}
The structural features of microalgal cell make it too difficult to extract the total lipid content of the cell as such. Thus, the cell disruption before lipid extraction becomes mandatory and has to be cost-effective. In the present study various methods and combination of few methods were adopted for effective extraction in order to choose the most effective cell disruption method for the complete extraction of lipids from a selected indigenous freshwater isolate, Scenedesmus sp. NTEB03. Interestingly, we found that grinding and bead-beating method showed two fold increased lipid productivity $(23.2 \%)$ than the other methods tested. Biomass and lipid productivity of Scenedesmus sp., was found to be $0.0418 \mathrm{~g} \mathrm{~L}^{-1} \mathrm{~d}^{-1}$ and $4.3 \mathrm{mg} \mathrm{L}^{-1} \mathrm{~d}^{-1}$ respectively. Fatty acid profiles revealed that oleic $(\mathrm{C} 18: 1)$ and linoleic acid (C18:2) content being higher in the lipids, which are most appropriate for the biodiesel production. A novel strategy for most effective, simple method for cell disruption in Scenedesmus sp., was grinding/bead-beating, which is the most suitable method for complete extraction of biofuel grade lipids.
\end{abstract}

Keywords: Biodiesel, Cell disruption, Lipid extraction, Scenedesmus sp. GC analysis.

\section{INTRODUCTION}

Microalgae are known as an economical and potential raw material for biofuels due to their efficient ability to convert sunlight and $\mathrm{CO}_{2}$ to biomass. Of the tremendous climatic changes and world demand of fossil fuel, it is urged to find alternate fuel sources. In the world scenario, alternate and renewable fuel from bioresources would be much better than other sources. From past two decades researchers have paid attention on biofuel from plants, animals and algae and other resources [1]. Biofuels are renewable, nontoxic and biodegradable and eco-friendly in the sense that their combustion will produce little, if any, emission of harmful green house gases [2]. Due to limitation of other resources, microalgae based oil is considered to be a promising candidate for biofuel. Microalgae have diverse beneficial features such as good biomass productivity, rapid lipid accumulation, ability to grow in fresh water to marine waters including of waste waters. They are well known to accumulate maximum amount of lipids and widely used as feedstock for biodiesel production [3]. There are notable advantages of producing oil from microalgae than other higher plants,

*Address correspondence to this author at the Department of Microbiology, Bharathidasan University, Tiruchirappalli 620024, Tamil Nadu, India; Tel: +91 431 2407082; Fax: +91 431 2407042; E-mail: thajuddin@gmail.com such as cultivation do not require much land, rate of photosynthetic efficiency, biomass production and growth rate are higher than the rest [4-6].

The microalgal lipid extraction is known to increase with the degree of cell disruption. During cell disruption, cells are disintegrated, intracellular lipids and cellular structures are liberated into the microenvironment [710]. The steps involved in biodiesel production are cultivation, harvesting, lipid extraction and the transesterification of the lipids. Even though all these steps are essential, cell disruption is particularly important, as the quantity of lipid extracted was determined by the disruption method used [9]. Therefore it is very important that the method employed for cell disruption should ensure the complete extraction of lipids.

There are several methods in practice for the extraction of lipids from diverse bioresources, such as microwaves, sonication, autoclave, osmotic shock, mechanical grinding, bead-beating, antibiotics, detergents, enzymes which could be make use in the disruption of microalgal cell for lipid extraction [9]. The microalgal lipid inclusions which are bound by membranes or cell walls are not readily available for extraction [11] and the recovery of such lipids can be 
improved upto three fold by disrupting the cells $[9,12]$. Although several methods have been described, a consistent method has not yet been standardized. Optimization of biomass production, harvest and extraction of lipid is mandatory for algal oil industry, which could make it cost-effective and simple. The present study analyzed various methods of cell disruption on an oleaginous microalga, Scenedesmus sp. and checked the suitability for feedstock to biodiesel production by comparing their biomass, lipid content and fatty acid profile. Outcome of the method can be directly utilized to oil industry for effective extraction in simple and cost-effective manner.

\section{MATERIALS AND METHODS}

\subsection{Culture Isolation and Growth}

Scenedesmus sp., NTEB03 was isolated from a stagnant fresh water body near Mathur, Tiruchirappalli district, Tamilnadu, India. The collected strain was maintained in the microalgal repository of the Department of Microbiology, Bharathidasan University, India. Culture was grown in Chu 10 medium under white photo-fluorescent light at a rate of $45 \mu \mathrm{Em}^{-2} \mathrm{~s}^{-1}$ with a photoperiod of $12 / 12 \mathrm{~h}$ light /dark at $24^{\circ} \mathrm{C}$ for 20 days. The Chu 10 medium comprised of $0.232 \mathrm{~g}$ of Calcium nitrate, $0.01 \mathrm{~g}$ of Dipotassium hydrogen phosphate, $0.025 \mathrm{~g}$ of Magnesium sulphate, $0.02 \mathrm{~g}$ of Sodium carbonate, $0.044 \mathrm{~g}$ of Sodium silicate, $3.5 \mathrm{mg}$ of Ferric ammonium citrate, $3.5 \mathrm{mg}$ of Citric acid, and $1000 \mathrm{ml}$ of distilled water. $1 \mathrm{ml}$ of trace metal mix comprising Boric acid (2.4g), Manganeous chloride $(1.4 \mathrm{~g})$, Zinc chloride $(0.4 \mathrm{~g})$, Calcium chloride $(0.02 \mathrm{~g})$ and Copper chloride $(0.1 \mathrm{~g})$ in $1000 \mathrm{ml}$ was also added to the medium.

\subsection{Measurement of Growth and Harvesting}

Growth rate of Scenedesmus sp. was determined by measuring the optical density. Briefly, about $2 \mathrm{ml}$ of well-shaken culture was drawn at an interval of two days. During every sampling, $2 \mathrm{ml}$ of fresh Chu 10 medium was added in order to compensate the acquired volume. Optical density was measured at 600 nm using UV-vis spectrophotometer (Cary 60, Agilent, USA). The biomass was harvested by centrifugation and was lyophilized for $24 \mathrm{hrs}$ under vacuum.

\subsection{Disruption of Cells}

An aliquot of $500 \mathrm{mg}$ of the cell biomass was resuspended in $100 \mathrm{ml}$ of distilled water and the mixture was subjected to disruption using 8 different methods as follows: 1) Autoclaving at $121^{\circ} \mathrm{C}$ for 5 minutes 2) bead-beating using a bead beater (bead diameter $0.1 \mathrm{~mm}$ ) at a high speed of $3000 \mathrm{rpm}$ for 10 min. 3) microwave method using a microwave oven at a high temperature for $5 \mathrm{~min} 4$ ) sonication using an ultra sonicator (JY92-IIN,USA) at a resonance of 15 $\mathrm{kHz}$ for $5 \mathrm{~min} 5$ ) osmotic shock using a $10 \% \mathrm{NaCl}$ solution with a vortex for $5 \mathrm{~min}$ and incubated for two days 6) mechanical grinding with a mortar and pestle for 5 min 7) keeping in water bath at $70^{\circ} \mathrm{C}$ for 1 hour and 8) a combination of mechanical grinding and bead beating.

\subsection{Lipid Extraction}

The total lipids were extracted by mixing methanol:chloroform $(1: 2 \mathrm{v} / \mathrm{v})$ with the samples in a proportion of $1: 1$ using the modified method of Bligh and Dyer [13]. The mixture were transferred into a separatory funnel and shaken well for 20 minutes. Finally the extracted lipid was collected by evaporating the solvent under rotary vacuum evaporator. The total lipids collected from the sample were measured using an electronic balance.

\subsection{Fatty Acid Composition Analysis by Gas Chromatography}

Fatty acid methyl esters (FAME) were prepared by using a modified protocol [9]. Briefly, $50 \mathrm{mg}$ of samples were taken in a reflux tube, it was saponified with $1 \mathrm{ml}$ of saturated potassium hydroxide/methanol $(\mathrm{KOH}-$ $\mathrm{CH}_{3} \mathrm{OH}$ ) solution at $75^{\circ} \mathrm{C}$ for $10 \mathrm{~min}$, and then it was subjected to methanolysis with $\mathrm{HCl}(5 \%)$ in methanol at $75^{\circ} \mathrm{C}$ for another $10 \mathrm{~min}$. Thereafter the aqueous phase was extracted twice with ethyl acetate. The organic layer containing the FAME was then collected, dried over anhydrous sodium sulphate to remove any excess moisture content. The FAME was analyzed by Gas chromatography. Fatty acid composition analysis was performed by using the Gas chromatograph (Shimadzu GC 2014, Japan) with flame ionization detector (FID). $1 \mu \mathrm{l}$ of sample was injected into FAME WAX column (Restek,USA) (30mx32mmIDx25 $\mu \mathrm{m}$ film thickness). The temperature program was as follows: initial $140^{\circ} \mathrm{C}$ with $5 \mathrm{~min}$ hold; ramp $2^{\circ} \mathrm{C} / \mathrm{min}$ to $230^{\circ} \mathrm{C}$ with a $5 \mathrm{~min}$ hold. Column flow was set at $22.2 \mathrm{ml} / \mathrm{min}$. The instrument condition was as follows: carrier gas nitrogen: FID set at $260^{\circ} \mathrm{C}$, and split ratio of $10: 1$. The run time for a single sample was $55 \mathrm{~min}$. The components were identified by comparing with the standard fatty acids used. 


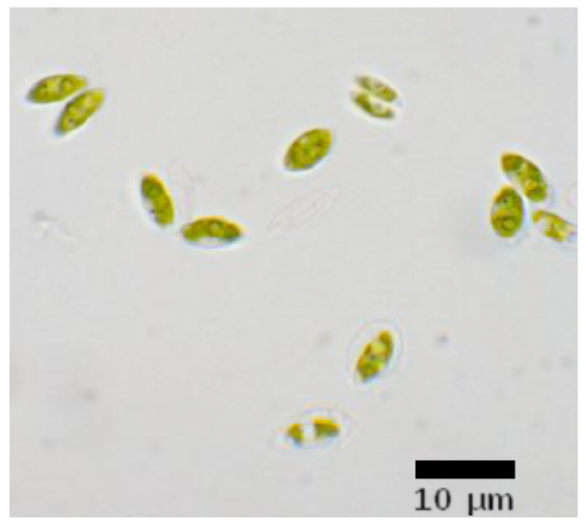

(a)

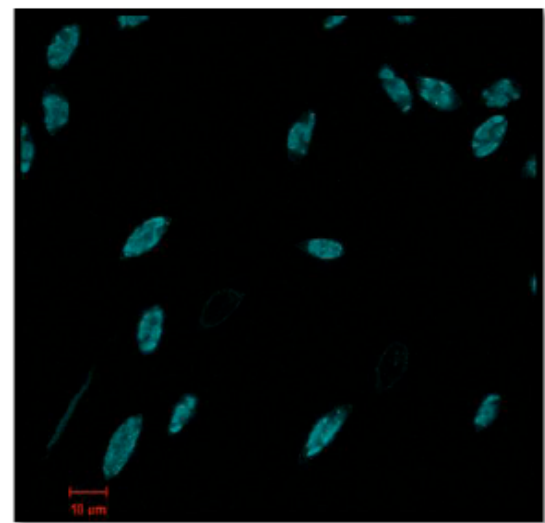

(b)

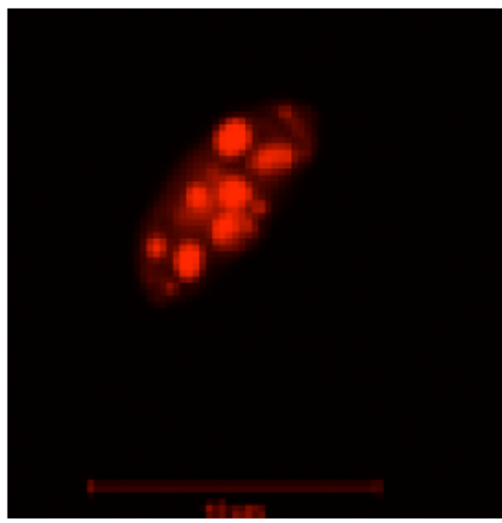

(c)

Figure 1: Microphotograph of Scenedesmus sp. NTEB03: Bright field (a); Confocal (b) and showing lipid inclusions stained by Nile Red (c).

\section{RESULTS AND DISCUSSION}

\subsection{Cell Growth and Harvest}

Microalgal sample was collected from a stagnant fresh water body near Mathur, Tiruchirappalli, Tamilnadu, India. In total five strains were isolated and morphologically identified using microphotographic system (Micros Austria) and documented namely Scenedesmus NTEB03, Chlorococcum NTEB09, Chlorella NTEB10, Spherocystis NTEB11, Scenedesmus NTEB12. All the isolated strains were deposited in the microalgal repository. Among the isolates Scenedesmus NTEB03 was found to be dominant and producing considerable amount of biomass. It was then chosen for further studies. According to our previous studies on the optimization of growth medium for Scenedesmus sp., Chu 10 was found to support well by significant increase in biomass. All the experiment and storage of the microalgae was done with Chu 10 medium [14]. The confocal microscopic image showing the lipid inclusions inside the strain using Nile red staining was shown in Figure 1. The growth curve of the isolate was studied from the optical density determined every two day interval from the day of inoculation (Figure 2). A clear idea about different phases of growth was obtained from the growth curve and the culture reached a stationary phase on 12th day of incubation. On the $16^{\text {th }}$ day of incubation the strain was found to enter the decline phase.

\subsection{Comparison of Cell Disruption Methods and Lipid Extraction}

Different types of disruption methods were used for the extraction of lipids and they are broadly divided into four categories; namely, mechanical, physical,

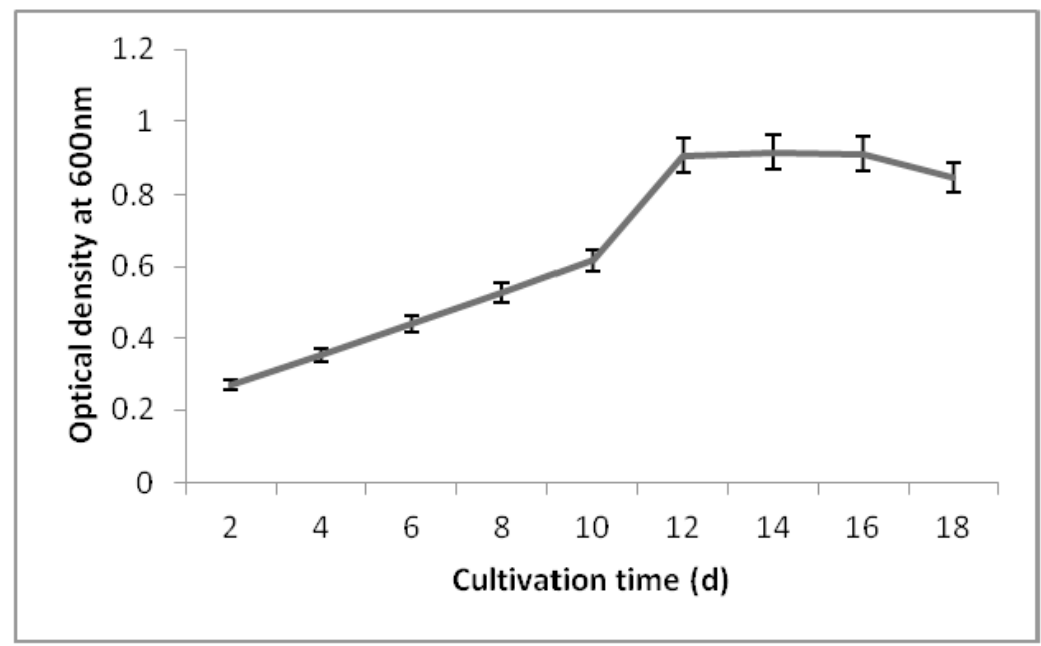

Figure 2: Growth curve of Scenedesmus sp. NTEB03, cultured in Chu 10 medium: stationary phase starts at the $12^{\text {th }}$ day. Data were the mean values and standard deviations of three replicates $(n=3)$. 


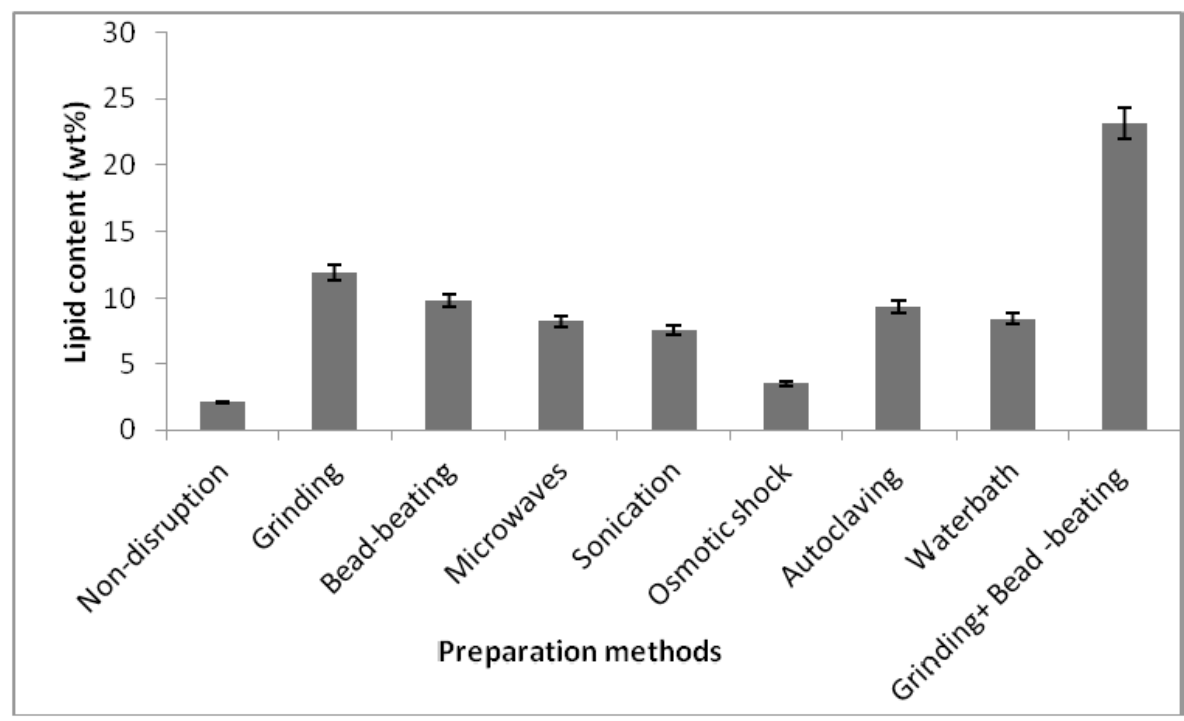

Figure 3: Lipid extraction efficiency according to different cell disruption methods for the Scenedesmus sp. NTEB03; grinding and bead-beating showed high lipid extraction of about $23.5 \%$. Data were the mean values and standard deviations of three replicates.

chemical and enzymatic but, an optimized disruption method has not yet been developed [15]. It was reported that a method that works well in one organism may not be the method of choice for another organism [16]. Thus, we attempted to standardize an efficient extraction method using a moderate lipid containing Scenedesmus sp. as a model organism. As reported earlier dry biomass of microalgae contains about 5 to 77 percentage of lipids, which has been found to vary in consistency from one species to another $[3,17]$.

In the study the quantity of lipid extracted by different cell disruption methods were found to be different for the same strain. The total lipid content of Scenedesmus sp. was found to vary $2 \%$ to $24 \%$ depending upon different cell disruption methods adopted (Figure 3 ). The lipid productivity of the Scenedesmus sp. was found as $4.3 \mathrm{mgL}^{-1} \mathrm{~d}^{-1}$ by grinding and bead-beating method. Very interestingly, combined method of grinding and bead-beating yielded two fold increased quantity $(23.16 \%)$ than those done separately. The method of osmotic shock using $10 \%$ $\mathrm{NaCl}$ solution was found to be $3.54 \%$ and all other methods extracted less than $9.5 \%$. Bead-beating and microwave oven method was reported as good in lipid extraction for Botryococcus sp. It has been reported that the microwave oven method was best method for the extraction of lipids from Scenedesmus sp. Furthermore, sonication method was better than microwaves, bead-beating, osmotic shock and autoclave for Scenedesmus sp. [18]. Bead beating that causes direct mechanical damage to cells where it was based on high-speed spinning with fine beads has been used both on a laboratory as well as in an industrial scale [19]. In this study it was found that a combination of mechanical grinding and bead-beating was the most effective method for lipid extraction from microalga, Scenedesmus sp NTEB03. It could be the method of choice for the lipid extraction and it can be scaled-up easily.

\subsection{Fatty Acid Composition}

The important properties of biodiesel including its ignition quality, combustion heat, cold filter plugging point (CFPP), oxidative stability, viscosity and lubricity which are highly dependent on the fatty acid composition [20]. The fatty acid profile of strain, Scenedesmus sp. NTEB03 was determined by gas chromatographic analysis. It was observed that Cis-10Heptadecanoic acid (C17:1); Oleic acid (C18:1) and Linoleic acid (C18:2) were found to be abundant in the extracted lipids (Table 2). Previous report mentioned that fatty acid profile of Scenedesmus sp. have about $36.8 \%$ polyunsaturated fatty acids (PUFA) containing

Table 1: Biomass, Lipid Contents and Productivity of Scenedesmus sp. NTEB03

\begin{tabular}{|c|c|}
\hline Item & Scenedesmus sp., \\
\hline \hline Incubation days & 14 \\
\hline Dry weight $\left(\mathrm{gL}^{-1}\right)$ & 0.5853 \\
\hline Biomass productivity $\left(\mathrm{mgL}^{-1} \mathrm{~d}^{-1}\right)$ & 41.8 \\
\hline Average lipid content $\left(\mathrm{mgL}^{-1}\right)$ & 59.6 \\
\hline Lipid productivity $\left(\mathrm{mgL}^{-1} \mathrm{~d}^{-1}\right)$ & 4.3 \\
\hline
\end{tabular}


Table 2: Fatty Acid Composition of Scenedesmus sp. NTEB 03 under Two Different Cell Disruption Methods

\begin{tabular}{|c|c|c|c|c|c|}
\hline $\begin{array}{c}\text { Sample } \\
\text { No. }\end{array}$ & & & Nature & Grinding + Beads beating & Grinding \\
\hline 2 & Cis-10-pentadecanoic & C15:1 & MUFA & 0.43 & ND \\
\hline 3 & Palmitic & C16:0 & SFA & 0.61 & 0.41 \\
\hline 5 & Elaidic & C18:1 & MUFA & 2.59 & ND \\
\hline 6 & Oleic & C18:1 & MUFA & 11.60 & 10.04 \\
\hline 7 & Linolelaidic & C18:2 & PUFA & 0.98 & 6.29 \\
\hline 8 & Linoleic & C18:2 & SFA & 34.23 & 32.72 \\
\hline 12 & Erucic & $\mathrm{C} 22: 1$ & MUFA & 0.49 & 5.39 \\
\hline 13 & Arachidonic & C20:4 & PUFA & 0.76 & ND \\
\hline 14 & Lignoceric & $\mathrm{C} 24: 0$ & SFA & ND & 7.92 \\
\hline 15 & Nervonic & $\mathrm{C} 24: 1$ & MUFA & 1.00 & 2.63 \\
\hline 16 & $\begin{array}{l}\text { Cis-4,7,10,13,16,19- } \\
\text { Decosahexaenoic }\end{array}$ & C22:6 & PUFA & 0.28 & ND \\
\hline
\end{tabular}

SFA- Saturated Fatty Acid, MUFA-Monounsaturated Fatty Acid, PUFA- Polyunsaturated Fatty Acid, ND- Not detected.

linoleic acid (21.1\%) and oleic acid (17.5\%) [21]. Whereas palmitic and linoleic acid were reported as the major fatty acids in the Scenedesmus sp. [22].

When the GC profiles from the grinding and grinding/bead-beating methods were compared it was found that there is significant difference among the fatty acid profiles. Fatty acids (C20:2, C24:0 and C22:1) were abundant from grinding method but barely detectable by the grinding/bead-beating method. Likewise the fatty acids C22:0 abundant in grinding/bead-beating method is not detected from grinding method, which implicates that the mode or methods used for lipid extraction influences the fatty acid profile also. So, further optimization in this regard could pave a way for exploring the complete biofuel potential of microlage.

Apart from the biofuel properties microlagal FAME from Scenedesmus sp. has extensively studied for antimicrobial property due to consistency of fatty acid [23]. There are some reports emphasizing that palmitic, stearic, oleic, linoleic acids are most common and important fatty acids in biodiesel [24, 25]. It is essential that the biodiesel must have high levels of saturated and monounsaturated fatty acids with low levels of polyunsaturated fatty acids [26]. According to the European standard EN14214 for biodiesel production the level of $\mathrm{C} 18: 3$ content has to be less or equal to $12 \%$. Here also it was seen to be less than $12 \%$. FAME profile showed a major content of fatty acids which is having high oxidative stability, thus can be stored for a longer time. High levels of saturated and monounsaturated fatty acids with low levels of polyunsaturated fatty acids favors the production of good quality biodiesel [2]. There are a good number of reports on different lipid induction methods for microlage [27]. Nutrient starvation (mainly nitrogen and phosphorous), salinity, $\mathrm{pH}, \mathrm{UV}$ irradiation etc being some of the important factors among them. There are specific reports on lipid induction in Scenedesmus sp. by nitrogen and phosphorous limitation [28-30]. Thus combining any suitable lipid induction method with the discussed grinding/bead beating extraction protocol, microalgae Scenedesmus sp. can be presented as a good biofuel feedstock. From a comparative investigation of previous reports, Scenedesmus sp. NTEB03 has got all the desirable features in agreement with biodiesel standards, was thus considered to be most suitable for the production of high quality biodiesel. 


\section{CONCLUSION}

Achieving a high quality and quantity of lipid from microalgae for the production of biodiesel greatly depends on the extraction in general and cell disruption in particular. In our study the Scenedesmus sp., was found to have a high lipid productivity of about $4.3 \mathrm{mgL}^{-}$ ${ }^{1} \mathrm{~d}^{-1}$. When using the combined method of grinding and bead-beating two fold increased lipid yield was obtained apart from using them separately. The quantity and quality of oleic (C18:1) and linoleic (C18:2) fatty acids also confirms that these methods can be used to extract the lipids from microalgae effectively. It is strategized that the combined method of grinding and bead-beating was most efficient, cost effective and simple method for extraction of algal lipids for biofuel production.

\section{ACKNOWLEDGEMENT}

Authors greatly acknowledge the Department of Biotechnology (Govt. of India), New Delhi for sanctioning the major project (BT/IN/IndoUK/SuBB/23/NT/2013), DST-PURSE for Confocal facility (SR/FT/LS-113/2009) and Deanship of Scientific Research, College of Science Research Center, King Saud University, Kingdom of Saudi Arabia. Corresponding author thanks to King Saud University, Riyadh, Kingdom of Saudi Arabia, for the Visiting Professorship.

\section{REFERENCES}

[1] Macedo N, Brigham CJ. From Beverages to Biofuels: The Journeys of Ethanol-Producing Microorganisms. Int J Biotech Well Indus 2014; 3(3): 79-87.

http://dx.doi.org/10.6000/1927-3037.2014.03.03.1

[2] Praveenkumar R, Johncy $\mathrm{K}$, Mubarak Ali $\mathrm{D}$ et al. Demonstration of increased lipid accumulation potential of Stigeoclonium sp., Kütz. BUM11007 under nitrogen starved regime: A new source of lipids for biodiesel production. J Biol Mater Bioenergy 2012; 6(2): 209-13 http://dx.doi.org/10.1166/jbmb.2012.1200

[3] Chisti Y. Biodiesel from microalgae. Biotechnol Adv 2007; 25: 294-306. http://dx.doi.org/10.1016/j.biotechadv.2007.02.001

[4] Milne TA, Evans RJ, Nagle N. Catalytic conversion of microalgae and vegetable oils to premium gasoline, with shape-selective zeolites. Biomass 1990; 21: 219-32. http://dx.doi.org/10.1016/0144-4565(90)90066-S

[5] Dote $Y$, Sawayama S, Inoue S, et al. Recovery of liquid fuel from hydrocarbon-rich microalgae by thermochemical liquefaction. Fuel 1994; 73: 1855-7.

\section{http://dx.doi.org/10.1016/0016-2361(94)90211-9}

[6] Minowa T, Yokoya SY, Kishimoto M, et al. Oil production from algae cells of Dunaliella Tereiolata by direct thermochemical liquefaction. Fuel 1995; 74: 1731-8. http://dx.doi.org/10.1016/0016-2361(95)80001-X
Chisti Y, Moo-Young M. Review: disruption of microbial cells for intracellular products. Enz Microb Technol 1986; 8: 194204.

http://dx.doi.org/10.1016/0141-0229(86)90087-6

[8] Gouveia L, Nobre BP, Marcelo FM, et al. Functional food oil colored by pigments extracted from microalgae with supercritical $\mathrm{CO}_{2}$. Food Chem 2007; 101: 717-23. http://dx.doi.org/10.1016/j.foodchem.2006.02.027

[9] Lee JY, Yoo C, Jun SY, et al. Comparison of several methods for effective lipid extraction from microalgae. Bioresour Technol 2010; 101: 75-7. http://dx.doi.org/10.1016/j.biortech.2009.03.058

[10] Mendes-Pinto MM, Raposo MFJ, Bowen J, et al. Evaluation of different cell disruption processes on encysted cells of Haematococcus pluvialis: effects on astaxanthin recovery and implications for bio-availability. J Appl Phycol 2001; 13: 19-24. http://dx.doi.org/10.1023/A:1008183429747

[11] Simon D, Helliwell S, Extraction and quantification of chlorophyll a from freshwater green algae. Water Res 1998; 32; 2220-3.

http://dx.doi.org/10.1016/S0043-1354(97)00452-1

[12] Boldor D, Kanitkar A, Terigar BG, et al. Microwave assisted extraction of biodiesel feedstock from the seeds of invasive Chinese tallow tree. Environ Sci Technol 2010; 44: 4019-25. http://dx.doi.org/10.1021/es100143z

[13] Bligh EG, Dyer WJ, A rapid method of total lipid extraction and purification. Can J Biochem Physiol 1956; 37: 911-7. http://dx.doi.org/10.1139/059-099

[14] Ilavarasi A, Mubarakali D, Praveenkumar R, et al. Optimization of various growth media to freshwater microalgae for biomass production. Biotechnology. 2013; 10: 540-5.

http://dx.doi.org/biotech.2011.540.545

[15] Middelberg APJ, Process-scale disruption of microorganisms. Biotechnol Adv 1995; 13: 491-551. http://dx.doi.org/10.1016/0734-9750(95)02007-P

[16] Ranjitha K, Kaushik BD, Purification of phycobiliproteins from Nostoc muscorum. J Sci Indus Res 2005; 64: 372-5.

[17] Brown MR, Jeffrey SW, Volkman JK, et al. Nutritional properties of microalgae for mariculture. Aquaculture. 1997; 151: 315-31. http://dx.doi.org/10.1016/S0044-8486(96)01501-3

[18] Pandian P, David Ravindran A. A study on effective lipid extraction methods from certain fresh water microalgae. Elixir Bio Tech 2011; 39: 4589-91. http://dx.doi.org/10.1111/j.1472-765X.2011.03082.x

[19] Geciova J, Bury D, Jelen P, Methods for disruption of microbial cells for potential use in the dairy industry-a review. Int Dairy J 2002; 12: 541-53. http://dx.doi.org/10.1016/S0958-6946(02)00038-9

[20] Knothe G, Dependence of biodiesel fuel properties on the structure of fatty acid alkyl esters. Fuel Process Technol 2005; 86: 1059-70.

\section{http://dx.doi.org/10.1016/j.fuproc.2004.11.002}

[21] Jena J, Nayak M, Panda HS, et al. Microalgae of Odisha Coast as a Potential Source for Biodiesel production. World Environ 2002; 2: 12-17. http://dx.doi.org/10.5923/j.env.20120201.03

[22] $\mathrm{Wu} \mathrm{YH,} \mathrm{Yu} \mathrm{Y,} \mathrm{Li} \mathrm{X.} \mathrm{Biomass} \mathrm{production} \mathrm{of} \mathrm{a} \mathrm{Scenedesmus}$ sp. under phosphorous-starvation cultivation condition. Bioresour Technol 2002; 112; 193-8. http://dx.doi.org/10.1016/j.biortech.2012.02.037

[23] Mubarak Ali D, Praveenkumar R, Shenbagavalli T, et al. New reports on anti-bacterial and anti-candidal activities of fatty acid methyl esters (FAME) obtained from Scenedesmus bijugatus var. bicellularis biomass. RSC Adv 2012; 2: 115526. 
[24] Knothe G, Designer biodiesel: optimizing fatty esters composition to improve fuel properties. Energy Fuel 2008; 22: $1358-64$ http://dx.doi.org/10.1021/ef700639e

[25] Rashid U, Anwar F, Moser BR, et al. Moringa oleifera oil: a possible source of biodiesel. Bioresour Technol 2008; 99; 8175-79.

http://dx.doi.org/10.1016/j.biortech.2008.03.066

[26] Baldev E, MubarakAli D, llavarasi A, et al. Degradation of synthetic dye, Rhodamine B to environmentally non-toxic products using microalgae. Colloids Surf B 2013; 105; 20714. http://dx.doi.org/10.1016/j.colsurfb.2013.01.008

[27] Sharma K K, Schuhmann H, Schenk PM, High Lipid Induction in Microalgae for Biodiesel Production. Energies 2012; 5: 1532-53.

http://dx.doi.org/10.3390/en5051532
[28] Gardner R, Peters P, Peyton B, et al. Medium $\mathrm{pH}$ and nitrate concentration effects on accumulation of triacylglycerol in two members of the chlorophyta. J Appl Phycol 2011; 23: 100516.

http://dx.doi.org/10.1007/s10811-010-9633-4

[29] Dean AP, Sigee DC, Estrada B, et al. Using FTIR spectroscopy for rapid determination of lipid accumulation in response to nitrogen limitation in freshwater microalgae. Bioresour Technol 2010; 101: 4499-507. http://dx.doi.org/10.1016/i.biortech.2010.01.065

[30] Xin L, Hong-ying $\mathrm{H}, \mathrm{Ke} \mathrm{G}$, et al. Effects of different nitrogen and phosphorus concentrations on the growth, nutrient uptake, and lipid accumulation of a freshwater microalga, Scenedesmus sp. Bioresour Technol 2010; 01: 5494-5500. http://dx.doi.org/10.1016/j.biortech.2010.02.016

Received on 10-11-2014

Accepted on 28-11-2014

Published on 06-01-2015

DOI: http://dx.doi.org/10.6000/1927-3037.2014.03.04.2

(c) 2014 Baldev et al.; Licensee Lifescience Global.

This is an open access article licensed under the terms of the Creative Commons Attribution Non-Commercial License (http://creativecommons.org/licenses/by-nc/3.0/) which permits unrestricted, non-commercial use, distribution and reproduction in any medium, provided the work is properly cited. 